Indonesian Journal of Global Health Research

Volume 3 Number 1, February 2021, pp. 9 - 14

e-ISSN 2715-1972; p-ISSN 2714-9749

http://jurnal.globalhealthsciencegroup.com/index.php/IJGHR

\title{
GAY'S SELF-ACCEPTANCE PROCESS ON HIV POSITIVE STATUS
}

\author{
Popy Apriyanti ${ }^{1 *}$, Dhesi Ari Astuti ${ }^{2}$ \\ ${ }^{1}$ STIKES Abdurahman Palembang, Jl. Suka Jaya No.7, Suka Bangun, Kec. Sukarami, Kota Palembang, \\ Sumatera Selatan, Indonesia 30151 \\ ${ }^{2}$ Universitas Aisyiyah Yogyakarta, Mlangi Nogotirto, Jl. Siliwangi Jl. Ringroad Barat No.63, Area Sawah, \\ Nogotirto, Gamping, Sleman, Yogyakarta, Indonesia 55592 \\ *popy.apriyanti@gmail.com
}

\begin{abstract}
Men with a homosexual orientation are more likely to experience depression than women who have a homosexual orientation. The purpose of this study was to conclude and examine the literatures related to the process of self-acceptance of Gays who were HIV positive. The method used was literature review by searching indexed articles from several database sources such as from PubMed, Proquest Disbursement of databases, scanning, and screening. In the search for the articles, 832 articles were identified. In addition, after filtering the titles, abstracts, and research methods, 103 articles were obtained to be taken and reviewed independently based on the inclusion and exclusion criteria. Then, a further article screening was carried out to find accurate and complete references regarding the self-acceptance process for ga MSM who were HIV positive and obtained 10 articles for a critical appraisal. The author filtered the articles based on the critical appraisal results and obtained 4 articles for a final review based on the period of 2013 to 2018, and identified using an electronic database. The findings showed the process of self-acceptance of gay people who are HIV positive. The responses when they first found out that they were HIV positive mostly showed the same response, namely experiencing anxiety, shock, distrust and rejection of the HIV test results in the form stress and depression. Over time, the informants accepted themselves as HIV positive sufferers in a resigned and strong form. Most of them had not disclosed their HIV status, especially to their partners and families because they were afraid of rejection and stigma.
\end{abstract}

Keywords: HIV; GAY; MSM

\begin{tabular}{|c|c|c|}
\hline $\begin{array}{c}\text { First Received } \\
12 \text { December } 2020\end{array}$ & $\begin{array}{c}\text { Revised } \\
15 \text { December } 2020\end{array}$ & $\begin{array}{c}\text { Accepted } \\
28 \text { December } 2020\end{array}$ \\
\hline $\begin{array}{c}\text { Final Proof Received } \\
\text { 02 January } 2021\end{array}$ & & $\begin{array}{c}\text { Published } \\
\text { 01 February } 2021\end{array}$ \\
\hline $\begin{array}{l}\text { How to cite (in APA style) } \\
\text { Yanti, P., \& Astuti, D. (2021). Gay's } \\
\text { Global Health Research, 3(1), 9-14. h }\end{array}$ & $\begin{array}{l}\text { ceptance Process o } \\
\text { i.org/10.37287/ijgh }\end{array}$ & $\begin{array}{l}\text { ositive Status. Indonesian Journal of } \\
2\end{array}$ \\
\hline
\end{tabular}

\section{INTRODUCTION}

Indonesia is one of the countries in the top five with the largest population in the world. Indonesia is in the fourth place with a population of 253.60 million and followed by Brazil with 202.65 million (Purnomo, 2014). This growth in population can cause more complex problems, one of which is health problems. Based on the data from the Ministry of Health (2015), groups at risk for HIV/AIDS are drug users who use needles, heterosexuals, male sex workers (MSM) who have multiple partners, and others who are not identified. The number of people living with HIV/AIDS among drug users is 802, 9,873 heterosexual, 4,241 male sex (MSM), and 4,677 unidentified people. From these data, it can be seen that MSM accounts for a fairly large proportion of the statistics for people with HIV/AIDS. Laksana (2010) stated that homosexual men have a higher risk factor for HIV/AIDS transmission than heterosexual men, especially through more than one sexual partner and anal sexual behavior. 
In terms of gender, men with a homosexual orientation are more likely to experience depression than women who have a homosexual orientation. Research conducted by Larasati (2012) showed that lesbians have a lower depression score than gay people. This is because women have a larger social group than men. Therefore, researchers were very interested in conducting this research.

\section{METHOD}

In accordance with the objectives and research questions, the literature used in this study was obtained through a comprehensive search system. The research question was, "How is the acceptance of Gay who is HIV positive?". This research has conducted a review through the sampling method. The literature search method in this study was in the period of 2013 to 2018, and was identified using the electronic database from PubMed, database disbursement Proquest, scanning, and article screening which were carried out independently by the researchers. Researchers followed the requirements in fulfilling the inclusion criteria, in which from 832 articles, after filtering titles, abstracts, research methods, 4 articles were used.

Table 1.

Search Method

\begin{tabular}{lcc}
\hline & All Fields & HIV \\
\hline OR & Human Immunodeficiency Virus \\
AND & Homosexuality \\
OR & Homosexual \\
OR & GAY \\
AND & Social Stigma \\
\hline
\end{tabular}

Table 2.

Framework for Inclusion and Exclusion Criteria

\begin{tabular}{lcc}
\hline \multicolumn{1}{c}{ Criteria } & Inclusion & Exclusion \\
\hline Population / Problem & Gay / homosexual / homosesuality & All women, \\
\cline { 1 - 2 } Exposure / Event & (Human Immunodeficiency Virus) HIV positive & Heterosexual \\
\cline { 1 - 2 } Outcomes & Social stigma & \\
\cline { 1 - 2 } Study Design & Qualitative study & \\
\hline
\end{tabular}

Table 3. Themes Findings

\begin{tabular}{lll}
\hline \multicolumn{1}{c}{ Theme } & \multicolumn{1}{c}{ Sub-themes } & \multicolumn{1}{c}{ Article } \\
\hline Disturbance anxiety & - Courage and Stigma & (choi, 2016), \\
& - Discrimination from health workers & (Rachel, 2013), \\
& - Community discrimination & (Wayenez, 2016) \\
\hline Support and potential role of & - Spouse/family support & (Tomoori, 2017) \\
MSM in HIV prevention & - Community support & \\
\hline
\end{tabular}

The sub-themes that appear in the 4 articles are described in table 4 and then categorized into two major themes, namely:

1. Anxiety Disorders

2. HIV positive support and prevention 


\section{RESULTS \\ Article Characteristics and Thematic Analysis}

Systematic Literature Review was carried out based on the characteristics of the study with inclusion criteria, including gay/MSM who are HIV positive sufferers 2) gay self-acceptance, 3) Full text, articles from the period of 2013-2018, and published in international juornal. The process of selecting articles was determined according to the inclusion criteria. Sources of the information were obtained from databases, namely PubMed and Proquest. The search strategy method for obtaining journals used terms HIV, Human Immunodeficiency Virus, homosexuality, homosexual, and used Advance Search "OR" Gay, sexual and gender minorities and uses Advance Search "AND" social stigma. The data collection process uses data extraction methods with the PEOS approach (Population, Exposure/event, Outcame, and Study Design). The articles data were extracted in the form of Title/ Author/ Year/ Grade, Country, Objective, Type of research, Data Collection, and Participants/ Sample size. The method used to critique journal articles used was the Critical Appraisal Skills Program (CASP) instrument. This instrument identifies literature through screening questions which then can be continued through Detailed Questions. This method is to reduce the bias in this Systematic Literature Review study. The synthesis forms that was presented in the systematic literature review were identification, screening, eligibility, and the presentation of the data, including diagram flow of the data results.

The identification results from the Search Method, PUBMED obtained 290 search results data, and Proquest obtained 542 search results data. Researchers conducted screening among the results of the same type of search data and the same research title. After the Screeaning stage was carried out, the Eligibility stage was done, namely the suitability of the search data with the inclusion criteria set by the researchers including the discovery of Gay with HIV positive 2) Self-acceptance process, 3) Full text, Articles from the period of 2013-2018, and published in International juornal. The study results obtained many results and the screening was carried out to the eligibility to obtain documents that matched the research study criteria. Based on the results of the synthesis, three documents that matched the criteria of the study were obtained. Furthermore, in-depth analysis (critical thingking) was carried out to obtain the best evidence in application. The process of self-acceptance of HIV positive gays is research of the highest quality. The results of the research literature had high reliability and the results were reliable.

\section{Anxiety Disorders}

Based on the findings of 3 articles, the author divided the process of self-acceptance with HIV positive gays with anxiety disorders (Choi, 2016, Rachel, 2013, Waynez, 2016). Anxiety disorder is mental health disorder characterized by strong feelings of worry, shame, anxiety, or fear, where respondents feel afraid of being shunned by their closest people, especially their partners (Choi, 2016).

Almost all respondents hid their HIV status either to their spouse/family, friends or to health services. Anxiety disorder about HIV positive status results from fear and stigma (Choi, 2016, Rachel, 2013, Waynez, 2016) of physical or psychological abuse and fear of abandonment and discrimination in society (Choi, 2016, Rachel, 2013, Waynez, 2016))). As stated by one respondent:

"I am afraid that if I tell my partner about my HIV positive status, he will leave me" (Choi, 2106) 
The notification of HIV positive status will cause stigma and discrimination in the community and health services experienced by respondents in Uganda. In accordance with what the respondents said:

"I hate going to the hospital, you know I feel humiliated there, the health worker there humiliated me and he told everyone about my HIV positive and gay status. They make me feel angry and upset to seek treatment" (Rachel, 2013 and Waynezz, 2016)

\section{Support and Role of MSM in HIV prevention \\ Support}

Support from spouses/families, peer support and the community can increase adherence to ARV use (Tomoori, 2017). As the Respondent said:

"They always support and accompany me in undergoing HIV treatment" (Tomoori., 2017).

\section{Role of MSM in HIV positive prevention}

The role of MSM is addressing norms for HIV-risk reduction, sexual communication skills and support for consistent condom use, as well as the use of HIV-services in the context of local socio-cultural norms.

\section{DISCUSSION}

The results of a systematic Literature review study found that the self-identification of HIV sufferers in Gay is related to the discovery of HIV sufferers of MSM scared of losing their partners and their loved ones in addition to health care providers and HIV counselors who are not consistent in providing health services. Currently, respondents are still struggling with the pressure of the effects of HIV disease and to take ARV treatment (Choi, 216).

Almost all respondents hid their HIV status either to their spouse/family, friends or to health services. Anxiety disorders about HIV positive status resulted from fear and stigma (Choi, 2016, Rachel, 2013, Waynez, 2016). Based on the results of the review, it showed that the perceived stigma and discrimination of men who were identified as gay HIV positive was because they were considered to be at risk due to the infection as well as high sexual, physical and verbal abuse victimization.

These findings provide important lessons for efforts to improve HIV-related outcomes for MSM. Community-mobilization and empowerment are the main pillars of this approach (Rachel, 2013). The results of the data could be that MSM faces difficulty in addressing their health needs to health care providers who understand them. (Waynes, 2016) They reported that when they seek health services from other and friendly providers, they feel comfortable explaining their problems (Tomoori, 2017).

The review above is in line with research conducted by Jeffries IV, Townsend, Gelaude, Torrone, Gasiorowicz, and Bertolli in 2015 with entitled HIV Stigma Experienced by Young Men Who Have Sex with Men (MSM) Living with HIV Infection. The results of this study were that the stigma obtained from the environment makes respondents reluctant to disclose their HIV status and tends to avoid things related to HIV. Based on the research conducted by Alex Dubov, 2018, respondents experienced stigma from various sides, as rejection by potential/actual partners, social stereotypes or chemsex, so these findings indicated the need to develop tailored interventions to address the stigma associated with PrEP and embarrassment for individuals, professionals. health, and society-at-great MSM. Therefore, support from spouses/ families, peer support and community can increase compliance with ARV use (Tomoori, 2017). 
This research is important to do in order to provide an overview of the self-acceptance process for gay/MSM who were HIV positive and it is expected that it can add information about selfacceptance of gay people who were HIV positive, so that they can develop appropriate intervention, promotive, and preventive models, especially for gay/ MSM who were HIV positive.

\section{CONCLUSION}

The process of self-acceptance of gay people who are HIV positive includes the responses when they first found out that they were HIV positive. They mostly showed the same response, which is by experiencing anxiety, shock, distrust and rejection of the HIV test results in the form of stress and depression. Over time, the informants accepted themselves as HIV positive sufferers in a resigned and strong form. Most of them had not disclosed their HIV status, especially to their partners and families because they were afraid of rejection and stigma.

\section{REFERENCES}

Choi. et al. (2017) 'Unpacking the Influence of Sexual Stigma on HIV Risk: Results From a Prospective Study of Men Who Have Sex With Men in Beijing, China.', Midwifery. Elsevier ,. doi: 10.1097 / QAI.0000000000001217.

'Critical Appraisal Skills Program (CASP) part of Oxford Center for Triple Value Healthcare Ltd www.casp-uk.net' (1994), (2018).

Green, L \& Kreuter M. Health Promotion Planning An Educational and Environmental Appoarch. Second Edition, Mayfield Publication Company Mountain View Toronto London; 2003

Dubov, et al.Stigma and Shame Experiences by MSM Who Take PrEP for HIV Prevention: A Qualitative Study, Midwifery. Elsevier ,. doi: 10.1177 / 1557988318797

Herdiansyah, H. (2016). Qualitative research methodology for the social sciences. Jakarta: Salemba Humanika.

Herek GM. CJ. Public Reactions to AIDS in The United States: A Second Decade of Stigma. Am J Public Health

Jevries. Et al (2015) 'HIV STIGMA EXPERIENCED BY YOUNG MEN WHO HAVE SEX WITH MEN (MSM) LIVING WITH HIV INFECTION, Midwifery. Elsevier ,. The Guilford Press.

King.et al (2016) 'Men at risk; a qualitative study on HIV risk, gender identity and violence among men who have sex with men who report high risk behavior in Kampala, Uganda period ', Plos One. doi: 10.1371 / journal.pone.0082937.

Smit, PJ, Brady, M., \& Thompson, M. (2012). HIV-related stigma within communities of gay men. AIDS care, psychological and socio-medical aspects of AIDS / HIV, 24 (4), 405412.

Smith, JA, Flowers, P., \& Larkin, M. (2010). Interpretative phenomenological analysis: Theory, method, and research. London: Sage Publication.

Taylor, SE (2012). Health psychology, eighth edition. New York: McGraw-Hill. 
Tomori. (2018) 'Friends, Sisters, and Wives: Social Support and Social Risks in Peer Relationships Among Men Who Have Sex With Men (MSM) in India). doi: 10.1521 / aeap.2016.28.2.153

Wanyenze. et al. (2017) '"If You Tell People That You Had Sex with a Fellow Man, It Is Hard to Be Helped and Treated": Barriers and Opportunities for Increasing Access to HIV Services among Men Who Have Sex with Men in Uganda, Plos One doi : 10.1371 / journal.pone.0147714.

WHO. (2012). Number of People All Ages Livving With HIV Situation, And Trends, Geneva. Word Health Organization.

World Health Organization. (2018)Intrapartum care for a positive childbirth experience. Geneva: World Health Organization. 